\title{
Surgeons' Views about Defensive Medicine
}

Cüneyt Destan Cenger, $\mathrm{MD}^{1}$, Giray Kolcu, MD, $\mathrm{PhD}^{2^{*}}$

${ }^{1}$ Department of Forensic Medicine, Istanbul University, Istanbul School of Medicine, Istanbul, Turkey
${ }^{2}$ Medical Education and Informatics Department, Isparta, Turkey

DOI: $10.36347 /$ sasjs.2020.v06i04.002

| Received: 23.03.2020 | Accepted: 31.03.2020 | Published: 05.04.2020

*Corresponding author: Giray Kolcu

\section{Abstract}

Introduction: Defensive medicine is defined as medical practices performed by physicians for diagnosing and treating their patients to protect themselves from the risk of criminal or civil actions. The use of defensive medicine is frequently discussed all over the world due to consequent judicial processes and accompanying costs. Objective: This study aimed to evaluate defensive medicine in general surgery, which is considered to be associated with a high risk of medical malpractice suits. Method: The study was designed as a cross-sectional descriptive study. The universe of the study comprised faculty members, specialists, and resident physicians working in the Trauma and Emergency Surgery Outpatient Clinic and General Surgery Department of Istanbul University, School of Medicine. The 'Defensive Medicine Behavior Scale' (DMBS) developed by Başer et al. was selected as a tool to collect study data[1]. The data were collected in face-to-face interviews in January 2018. Results: Thirty-nine physicians participated in the study (n: 39). The mean age of the participants was $35.92 \pm 11.34$ years (min: 25 , max: 66). Of the participants, $79 \%$ were males and $20.5 \%$ were females. The mean DMBS score was $43.30 \pm 9.19$ (min: 22, max: 66). Of the participants; $76.9 \%$ reported that they heard about the concept of defensive medicine previously, $97.4 \%$ reported that defensive medicine negatively affect the performance of physicians, and 56.4\% reported that they were not adequately knowledgeable. A statistically significant association was found between the knowledge level of surgeons and defensive medicine (p: 0.006). Discussion: It was found out that the participating physicians practiced defensive medicine at moderate levels and that the knowledge level of physicians; who practiced defensive medicine more commonly, were high. The concept of defensive medicine is still very new in our country; therefore, we are of the opinion that it should be discussed more commonly in the academic environment.

Keywords: Medicine, Surgery, Defensive Medicine.

Copyright @ 2020: This is an open-access article distributed under the terms of the Creative Commons Attribution license which permits unrestricted use, distribution, and reproduction in any medium for non-commercial use (NonCommercial, or CC-BY-NC) provided the original author and source are credited.

\section{INTRODUCTION}

Defensive medicine refers to a collection of diagnostic tests, treatments, and procedures ordered by the physician to avoid patient-filed lawsuits rather than to diagnose and treat patients [2]. To avoid the risk of being sued; physicians request several tests and perform a lot of procedures and visits regardless of necessities, or they reject high-risk patients [3, 4]. Defensive medicine is categorized under two main headings as positive defensive medicine and negative defensive medicine [5]. Positive defensive medicine (assurance behavior) practices add additional services accepted by the service standards of the legal system only to avoid negative consequences and malpractice suits rather than providing marginal or medical benefits for the patient [6]. Negative defensive medicine (avoidant behavior) is performed by physicians to protect themselves against legal risks. For example; rejecting high-risk procedures and situations, avoiding invasive procedures, and removing high-risk patients from operating lists are such types of negative defensive practices [6].

A study investigating malpractice lawsuit verdicts reports that general surgery is the third leading branch of medicine with the third highest number of malpractice suits at a rate of $11.5 \%$. Similarly, several other studies in the literature report general surgery holding either of the first three ranks across other specialties of medicine with a high number of malpractice lawsuits filed against general surgeons [717]. It is reported that general surgeons are found at fault at a $33 \%$ rate in civil cases in local courts and that they are found at $23 \%$ fault in criminal cases in local courts [7]. Those high rates are associated with intensive workload and communication issues [18-20].

Our study aimed to evaluate the physicians' opinions about defensive medicine among surgeons working in the field of general surgery; which is a 
medical specialty at high risk of being sued for malpractice.

\section{MATERIALS AND METHODS}

The study was designed as a cross-sectional descriptive study. The universe of the study comprised faculty members, specialists, and resident physicians working in the Trauma and Emergency Surgery Outpatient Clinic and General Surgery Department of Istanbul University, School of Medicine. The 'Defensive Medicine Behavior Scale' (DMBS) developed by Başer et al. was used for collecting study data by using one of the most often used methods, the face-to-face interview technique. DMBS was administered in January 2018 to the faculty members, specialists, and resident physicians working in the General Surgery Department and the Department of Trauma and Emergency Surgery [1]. The scale was developed to grade and evaluate defensive medicine, consisting of questions about socio-demographic data and positive and negative defensive medicine. The Likert scale was used for scoring the responses given to questions about attitudes [1, 21, 22]. Positive negative medicine practices were scored across 14 questions and the potential responses to these questions included 'I completely agree', ' I agree very much', 'I agree moderately', 'I agree a little', and 'I do not agree at all'; each answer representing $20 \%$ of the respondents. The scores attributed to those answers were as follows: 'I completely agree with these statements' $=5$ points, 'I agree very much' $=4$ points, 'I agree moderately' $=3$ points, 'I agree a little' $=2$ points and 'I do not agree at all'=1 point. A total score was found for each physician. Aiming to grade physicians' attitude levels about defensive medicine, the total scores obtained from the scale were categorized as follows: very high levels: 7056 points, high levels: $55-42$ points, moderate levels: 41-28 points, and low levels: $27-14$ points. The questions $15,16,17$, and 18 scaled the level of knowledge with yes or no answers, each representing $50 \%$ of the respondents $[1,4]$.

Descriptive statistics were used in the statistical analysis. Priorities were calculated and tabulated based on percentage distributions. The responses; 'I agree a little' and 'I do not agree at all' were assigned to a 'no' answer; whereas the remaining ones were assigned to the 'yes' category. The chi-square test was used for testing the categorical data. The t-test was used for the comparison of DMBS scores. A p-value of $<0.05$ was considered statistically significant.

\section{RESULTS}

Thirty-nine surgeons working in the Trauma and Emergency Outpatient Clinic and General Surgery Department of Istanbul University's Istanbul School of
Medicine participated in the study. Of the participating surgeons; 21 (53.8\%) were resident physicians, 6 $(15.4 \%)$ were professors, $6(15.4 \%)$ were associate professors, and 6 were specialists. Since participating in the study was on a voluntary basis, a consent form was obtained from the participants. Of the participating surgeons, $31(79.5 \%)$ were males and $8(20.5 \%)$ were females. While the mean age of the study participants was $35.92 \pm 11.34$ years, the mean age was $28.62 \pm$ 5.79 years in the resident physicians and $44.44 \pm 10.28$ years in the group of specialists and faculty members. The distribution of the participants' responses to the DMBS questions is presented in Table 1.

It was observed that; compared to the specialists and faculty members, resident physicians ordered extra tests and provided their patients with as many prescriptions as possible within the limits of indication in order to protect themselves from liabilities ( $p<0.05)$. Female surgeons more often ordered extra tests and avoided patients with a high likelihood of filing lawsuits compared to their male colleagues ( $p$ $0.05)$. No statistically significant differences were observed in the positive and negative defensive medicine behaviors between the specialists and faculty members, males and females, and between the surgeons experienced in a patient-physician relationship for longer than 10 years compared to those with an experience of shorter than 10 years.

While the residents in general surgery had never been sued for malpractice cases, $33.3 \%$ of the general surgeons and faculty members in general surgery had been sued at least once due to medical malpractice during their careers.

Defensive medicine practice behavior levels of general surgeons are presented in Table 2. While defensive medicine was moderately practiced by general surgeons (specialists) and faculty members, it was practiced at high levels by the resident general surgeons. The distribution of the defensive medicine practice attitude levels of the general surgeons by their academic titles is presented in Table 3 .

The majority of general surgeons practiced defensive medicine at moderate and high levels. The practice level of negative and positive defensive medicine was not significantly different across resident general surgeons, specialists, and faculty members ( $\mathrm{p}>$ $0.05)$.

A statistically significant association was found between the knowledge level of surgeons and defensive medicine (p: 0.006). 
Table-1: Distribution of participant responses to DMSB questions

\begin{tabular}{|c|c|c|c|c|c|}
\hline $\begin{array}{l}\text { Questions about the level of positive } \\
\text { defensive medicine behaviors }\end{array}$ & $\begin{array}{l}\text { I agree } \\
\text { completely }\end{array}$ & $\begin{array}{l}\text { I agree very } \\
\text { much }\end{array}$ & $\begin{array}{c}\text { I agree } \\
\text { moderately }\end{array}$ & $\begin{array}{l}\text { I agree a } \\
\text { little }\end{array}$ & $\begin{array}{l}\text { I do not agree } \\
\text { at all }\end{array}$ \\
\hline $\begin{array}{l}\text { 1. In order to protect myself from legal risks, I } \\
\text { order tests for my patients other than what I } \\
\text { consider necessary. }\end{array}$ & $\begin{array}{c}7 \\
(17.9 \%)\end{array}$ & $\begin{array}{c}5 \\
(12.8 \%)\end{array}$ & $\begin{array}{c}12 \\
(30.8 \%)\end{array}$ & $\begin{array}{c}9 \\
(23.1 \%)\end{array}$ & $\begin{array}{c}6 \\
(15.4 \%)\end{array}$ \\
\hline $\begin{array}{l}\text { 2. In order to protect myself from legal risks, I } \\
\text { prescribe as much medicine as possible to my } \\
\text { patients as long as they are indicated. }\end{array}$ & $\begin{array}{c}3 \\
(7.7 \%)\end{array}$ & $\begin{array}{c}7 \\
(17.9 \%)\end{array}$ & $\begin{array}{c}13 \\
(33.3 \%)\end{array}$ & $\begin{array}{c}10 \\
(25.6 \%)\end{array}$ & $\begin{array}{c}6 \\
(15.4 \%)\end{array}$ \\
\hline $\begin{array}{l}\text { 3. In order to protect myself from legal risks, I } \\
\text { request extra consultations for my patients for } \\
\text { potential complications. }\end{array}$ & $\begin{array}{c}7 \\
(17.9 \%)\end{array}$ & $\begin{array}{c}14 \\
(35.9 \%)\end{array}$ & $\begin{array}{c}11 \\
(28.2 \%)\end{array}$ & $\begin{array}{c}4 \\
(10.3 \%)\end{array}$ & $\begin{array}{c}3 \\
(7.7 \%)\end{array}$ \\
\hline $\begin{array}{l}\text { 4. In order to protect myself from legal risks, I } \\
\text { hospitalize patients for reasons other than } \\
\text { indications (e.g. social admission). }\end{array}$ & $\begin{array}{c}3 \\
(7.7 \%)\end{array}$ & $\begin{array}{c}9 \\
(23.1 \%)\end{array}$ & $\begin{array}{c}5 \\
(12.8 \%)\end{array}$ & $\begin{array}{c}12 \\
(30.8 \%)\end{array}$ & $\begin{array}{c}10 \\
(25.6 \%)\end{array}$ \\
\hline $\begin{array}{l}\text { 5. In order to protect myself from legal risks, I } \\
\text { order imaging tests more often than I would do } \\
\text { normally do. }\end{array}$ & $\begin{array}{c}9 \\
(23.1 \%)\end{array}$ & $\begin{array}{c}12 \\
(30.8 \%)\end{array}$ & $\begin{array}{c}8 \\
(20.5 \%)\end{array}$ & $\begin{array}{c}8 \\
(20.5 \%)\end{array}$ & $\begin{array}{c}2 \\
(5.1 \%)\end{array}$ \\
\hline $\begin{array}{l}\text { 6. In order to protect myself from legal risks, I } \\
\text { explain medical practices in extra detailed } \\
\text { ways to my patients. }\end{array}$ & $\begin{array}{c}11 \\
(28.2 \%)\end{array}$ & $\begin{array}{c}15 \\
(38.5 \%)\end{array}$ & $\begin{array}{c}9 \\
(23.1 \%)\end{array}$ & $\begin{array}{c}2 \\
(5.1 \%)\end{array}$ & $\begin{array}{c}2 \\
(5.1 \%)\end{array}$ \\
\hline $\begin{array}{l}\text { 7. In order to protect myself from legal risks, I } \\
\text { allocate extra time for my patients. }\end{array}$ & $\begin{array}{c}5 \\
(12.8 \%)\end{array}$ & $\begin{array}{c}7 \\
(17.9 \%)\end{array}$ & $\begin{array}{c}19 \\
(48.7 \%)\end{array}$ & $\begin{array}{c}7 \\
(17.9 \%)\end{array}$ & $\begin{array}{c}1 \\
(2.6 \%)\end{array}$ \\
\hline $\begin{array}{l}\text { 8. In order to protect myself from legal risks, I } \\
\text { keep extra-detailed patient records. }\end{array}$ & $\begin{array}{c}8 \\
(20.5 \%)\end{array}$ & $\begin{array}{c}14 \\
(35.9 \%)\end{array}$ & $\begin{array}{c}9 \\
(23.1 \%)\end{array}$ & $\begin{array}{c}8 \\
(20.5 \%)\end{array}$ & $\begin{array}{c}0 \\
(0 \%)\end{array}$ \\
\hline $\begin{array}{l}\text { 9. In order to protect myself from legal risks, I } \\
\text { exercise extra care in informed consent } \\
\text { procedures. }\end{array}$ & $\begin{array}{c}14 \\
(35.9 \%)\end{array}$ & $\begin{array}{c}15 \\
(38.5 \%)\end{array}$ & $\begin{array}{c}7 \\
(17.9 \%)\end{array}$ & $\begin{array}{c}3 \\
(7.7 \%)\end{array}$ & $\begin{array}{c}0 \\
(0 \%)\end{array}$ \\
\hline $\begin{array}{l}\text { Questions about the level of negative } \\
\text { defensive medicine behaviors }\end{array}$ & $\begin{array}{c}\text { I agree } \\
\text { completely }\end{array}$ & $\begin{array}{c}\text { I agree very } \\
\text { much }\end{array}$ & $\begin{array}{c}\text { I agree } \\
\text { moderately }\end{array}$ & $\begin{array}{c}\text { I agree a } \\
\text { little }\end{array}$ & $\begin{array}{l}\text { I do not agree } \\
\text { at all }\end{array}$ \\
\hline $\begin{array}{l}\text { 10. In order to protect myself from legal risks, I } \\
\text { avoid admitting patients likely to pose risks for } \\
\text { lawsuits. }\end{array}$ & $\begin{array}{c}6 \\
(15.4 \%)\end{array}$ & $\begin{array}{c}3 \\
(7.7 \%)\end{array}$ & $\begin{array}{c}14 \\
(35.9 \%)\end{array}$ & $\begin{array}{c}12 \\
(30.8 \%)\end{array}$ & $\begin{array}{c}4 \\
(10.3 \%)\end{array}$ \\
\hline $\begin{array}{l}\text { 11. In order to protect myself from legal risks, I } \\
\text { avoid patients with complex medical problems. }\end{array}$ & $\begin{array}{c}3 \\
(7.7 \%)\end{array}$ & $\begin{array}{c}5 \\
(12.8 \%)\end{array}$ & $\begin{array}{c}8 \\
(20.5 \%)\end{array}$ & $\begin{array}{c}18 \\
(46.2 \%)\end{array}$ & $\begin{array}{c}5 \\
(12.8 \%)\end{array}$ \\
\hline $\begin{array}{l}\text { 12. In order to protect myself from legal risks, I } \\
\text { avoid treatment protocols associated with high } \\
\text { complication rates. }\end{array}$ & $\begin{array}{c}1 \\
(2.6 \%)\end{array}$ & $\begin{array}{c}4 \\
(10.3 \%)\end{array}$ & $\begin{array}{c}11 \\
(28.2 \%)\end{array}$ & $\begin{array}{c}15 \\
(38.5 \%)\end{array}$ & $\begin{array}{c}8 \\
(20.5 \%)\end{array}$ \\
\hline $\begin{array}{l}\text { 13. In order to protect myself from legal risks, I } \\
\text { tend to prefer non-invasive treatment protocols } \\
\text { rather than invasive ones. }\end{array}$ & $\begin{array}{c}1 \\
(2.6 \%)\end{array}$ & $\begin{array}{c}2 \\
(5.1 \%)\end{array}$ & $\begin{array}{c}8 \\
(20.5 \%)\end{array}$ & $\begin{array}{c}17 \\
(43.6 \%)\end{array}$ & $\begin{array}{c}11 \\
(28.2 \%)\end{array}$ \\
\hline $\begin{array}{l}\text { 14. I feel uneasy in my medical practice as } \\
\text { malpractice issues gain considerable media } \\
\text { coverage. }\end{array}$ & $\begin{array}{c}9 \\
(23.1 \%)\end{array}$ & $\begin{array}{c}15 \\
(38.5 \%)\end{array}$ & $\begin{array}{c}8 \\
(20.5 \%)\end{array}$ & $\begin{array}{c}5 \\
(12.8 \%)\end{array}$ & $\begin{array}{c}2 \\
(5.1 \%)\end{array}$ \\
\hline
\end{tabular}

\begin{tabular}{|c|c|c|}
\hline Questions about the level of knowledge & Yes & No \\
\hline 15. Have you ever been sued for medical malpractice during your career? & $\begin{array}{c}6 \\
(15.4 \%)\end{array}$ & $\begin{array}{c}33 \\
(84.6 \%)\end{array}$ \\
\hline 16. Do you think that medical malpractice suits will affect your medical performance as a physician? & $\begin{array}{c}38 \\
(97.4 \%) \\
\end{array}$ & $\begin{array}{c}1 \\
(2.6 \%) \\
\end{array}$ \\
\hline 17. Have you ever heard of the concept of defensive medicine? & $\begin{array}{c}30 \\
(76.9 \%)\end{array}$ & $\begin{array}{c}9 \\
(23.1 \%)\end{array}$ \\
\hline 18. Are you knowledgeable enough about the concept of defensive medicine? & $\begin{array}{c}17 \\
(43.6 \%)\end{array}$ & $\begin{array}{c}22 \\
(56.4 \%)\end{array}$ \\
\hline
\end{tabular}


Table-2: Defensive medicine practice behavior levels of general surgeons

\begin{tabular}{|c|c|c|c|c|c|c|}
\hline \multicolumn{2}{|c|}{ Defensive medicine practice behavior level } & \multirow{2}{*}{$\begin{array}{c}\begin{array}{c}\text { Number } \\
\text { (n) }\end{array} \\
21 \\
\end{array}$} & \multirow{2}{*}{$\begin{array}{r}\text { Mean } \\
13.61 \\
\end{array}$} & \multirow[t]{2}{*}{ \pm} & \multirow{2}{*}{\begin{tabular}{|l|} 
Std. \\
Deviation \\
3.04
\end{tabular}} & \multirow{2}{*}{$\begin{array}{c}\text { Std. Error } \\
0.66\end{array}$} \\
\hline Negative defensive medicine behavior & Resident surgeons & & & & & \\
\hline level & $\begin{array}{l}\text { Specialists and faculty } \\
\text { members }\end{array}$ & 18 & 13.38 & \pm & 5.58 & 1.31 \\
\hline \multirow{2}{*}{$\begin{array}{l}\text { Positive defensive medicine behavior } \\
\text { levels }\end{array}$} & Resident surgeons & 21 & 31.52 & \pm & 5.59 & 1.22 \\
\hline & $\begin{array}{l}\text { Specialists and faculty } \\
\text { members }\end{array}$ & 18 & 27.77 & \pm & 6.91 & 1.63 \\
\hline \multirow[t]{2}{*}{ Defensive medicine behavior levels } & Resident surgeons & 21 & 45.14 & \pm & 7.22 & 1.57 \\
\hline & $\begin{array}{l}\text { Specialists and faculty } \\
\text { members }\end{array}$ & 18 & 41.16 & \pm & 10.89 & 2.56 \\
\hline Defensive medicine behavior levels & General surgeons & 39 & 43.30 & \pm & 9.19 & \\
\hline
\end{tabular}

Table-3: Distribution of defensive medicine practice attitude levels of general surgeons by their academic titles

\begin{tabular}{|c|c|c|c|c|c|c|}
\hline \multirow{2}{*}{ Behavior level } & \multicolumn{2}{|c|}{ Specialist + Faculty Member } & \multicolumn{2}{c|}{ Resident surgeons } & \multicolumn{2}{c|}{ Total } \\
\cline { 2 - 7 } & n (number) & \% (Percentage) & n (number) & \% (Percentage) & n (number) & \% (Percentage) \\
\hline Very high (56-70) & 2 & 11.1 & 2 & 9.5 & 4 & 10.3 \\
\hline High (42-55) & 7 & 38.9 & 12 & 57.1 & 19 & 48.7 \\
\hline Moderate (28-41) & 7 & 38.9 & 7 & 33.3 & 14 & 35.9 \\
\hline Low (14-27) & 2 & 11.1 & - & - & 2 & 5.1 \\
\hline
\end{tabular}

\section{DISCUSSION}

Medical malpractice lawsuits have become a common practice today. A study evaluating medical malpractice lawsuit decisions of the General Assembly of the Istanbul Forensic Medicine Institute reported that $33.3 \%$ of 330 cases were found at fault for "medical malpractice [23]".

General surgery is considered a high-risk field of medicine for medical practice. Several studies in the literature report that it is one of the leading specialties of medicine facing malpractice suits and/or complaints [6-9,11-13,15,17,24]. Distribution of malpractice suits and filed claims by the specialty areas in medicine reveals that surgeons are more often sued compared to other specialists, providing evidence that surgical interventions pose a considerably high risk for malpractice cases $[23,25,26]$.

Gürbeden et al. reported that general surgery held the fourth rank with a medical suit rate of $8.3 \%$. Can et al. [25]study evaluated 30 Supreme Court decisions on malpractice cases issued in the years from 1978 to 2006 and reported that general surgery was the leading specialty with a $31 \%$ rate across other areas of medicine with physicians being sued most commonly [12]. It was reported that malpractice cases filed against general surgeons accounted for $25.4 \%$ of all dossiers submitted to the Supreme Council of Health in the years between 1995 and 2000. When the frequency of malpractice cases was analyzed by the institutions, where the general surgeons worked, it was observed that general surgeons were found at fault at a $72 \%$ rate due to the interventions they performed in public hospitals [14]. A study, evaluating the Supreme Court decisions about faulty medical practices in the years between 2010 and 2017, reported that general surgery was the third leading specialty at an $11.5 \%$ rate of malpractice cases filed against surgeons. The same study also reported that local courts found general surgeons at fault in 10 (33\%) out of 30 civil cases and in $5(23 \%)$ out of 22 criminal cases. Can et al. [7] evaluated the distribution of the causes of malpractice across high judicial body decisions. They reported that general surgeons were the specialists, who were found at fault for malpractice most commonly (29\%) and that medical negligence was found most commonly (33\%) in general surgeons. Wanzel et al.[12] investigated the complications in general surgery and found errors in treatment and diagnoses in $72 \%$ and $28 \%$ of the malpractice cases, respectively [27].

An analysis of the malpractice compensation claims by the medical specialty in the database of the Third Specialty Council of the Forensic Medicine Institute (a total of 1280 claims and 707 confirmed faulty medical practices in 2009) revealed that general surgery was the second leading field of medicine in terms of the highest number of lawsuits $(n=22)$ [28].

Based on those study results reported in the literature, we included general surgeons in our study as general surgery is one of the leading medical specialties facing a high risk for malpractice claims.

The mean age of the general surgeons participating in our study was $35.92 \pm 11.34$ years and the mean age of the resident physicians (n: 21) was $28.62 \pm 5.79$. A similar study from our country, conducted on resident and specialist surgeons in gynecology and obstetrics, reported that the mean age was $36.61 \pm 8.87$ years. Another study reported the mean age in female and male physicians as 38.9 and 42.1 years, respectively. A study investigating the age distribution of physicians from Konya reported that; of 
the participants, $15.6 \%$ were 29 years old or younger, $36.4 \%$ were in the age range from 20 to 39 years, $37.6 \%$ were between the ages of 40 and 49 years, and $10.4 \%$ were 50 years old or older $[3,29,30]$. The medical specialty thesis study by Selçuk et al. reported that the mean age of the participating physicians was 38.6955 years. The mean age of our study population is parallel to the mean age values reported by previous studies from our country[31-33].

The studies about defensive medicine applications report male and female frequencies as $70.5 \%$ and $29.5 \%$, respectively. The medical specialty thesis study by Selçuk reported that; of the study participants, 55\% were males. Another study reported that $64.4 \%$ of the participants were males $[6,31,32$, 34]. Similarly, other studies in the literature report a male predominance in gender distribution $[3,6,29,30$, $33,35,36]$. In our study; of the participating general surgeons, $79.5 \%$ were males and $20.5 \%$ were females. The gender distribution in our study is parallel to those reported by previous studies about defensive medicine in our country.

The general surgeons participating in our study had a patient-physician relationship experience of 11.76 years. In the medical specialty thesis study by Kolcu, the length of the patient-physician relationship experience was reported to be 9.94 years. Another study reported that the length of physicians' careers was less than 9 years in $48 \%$, in the range from 10 to 19 years in $36.4 \%$, and 20 years or longer in $15.6 \%$ of the participants. Selcuk reported in the medical specialty thesis study that $50 \%$ of the participants had 1 to 10 years of experience, $20.5 \%$ had 11 to 20 years of experience, $19.1 \%$ had 21 to 30 years of experience, and $10.5 \%$ had longer than 31 years of experience $[3,22]$.

In Japan, a 10-fold increase was observed in the number of malpractice suits in the years between 1960 and 2003. The number of malpractice suits increased from 102 to 1019 cases. Although the number of medical malpractice litigations in Japan is relatively small compared to that in the United States (US), the figures in Japan appear to approach those of the US gradually [37]. A questionnaire study from the UK on 204 specialist physicians reported that; of the participants, $91 \%$ were of the opinion that the number of malpractice suits was on the rise, $14 \%$ were previously sued at least once, and $90 \%$ had indemnity insurance against malpractice compensation claims. In a survey study on 809 physicians working in specialties of internal medicine and surgery in Taiwan, Chen et al. observed that; of the participants, $56.5 \%$ experienced malpractice issues and $15.9 \%$ were sued [38]. A study on 877 physicians in Israel reported that $25 \%$ of the physicians were sued for malpractice at least once during their careers [39]. It is reported that the rate of being named in a malpractice lawsuit was $2.9 \%$ across resident physicians in Dokuz Eylul University. Selcuk and Göçen reported that physicians were sued for malpractice at a rate of $10.5 \%$. In another study, Başer reported the frequency of malpractice suits as $7.4 \%$. It has been reported that surgeons are sued 4.6 times more frequently compared to non-surgical specialties $[31,32,35]$. The medical specialty thesis study by Aynac1 from Konya in 2008 reported that the rate of malpractice suits against physicians was $12.34 \%$. In 2016, Özata et al. reported that the rate of malpractice investigations/litigations was $24.3 \%$ [30,40]. Another study was carried out in the same province 8 years later and determined an increase in the rate of medical malpractice lawsuits and complaints. Parallel to the information in the literature, our study revealed that the residents in general surgery had never been sued for malpractice but $33.3 \%$ of the specialists and faculty members in general surgery had been sued at least once due to medical malpractice during their careers. It was found out that malpractice claims were filed against $15.4 \%$ of the surgeons participating in our study.

Defensive medicine is defined as 'medical practices performed by physicians for diagnosis and treatment to protect themselves from the risk of criminal or civil actions'. To avoid the risk of being sued; physicians request several tests and perform a lot of procedures and visits regardless of necessities, or they reject high-risk patients [3]. Defensive medicine (DMP) constitutes a subject of debate globally. Several studies report that such practices are commonly performed by physicians. DMP have been reported to be performed by physicians in a range from 60 to $98 \%$ in the literature $6,30,32,34,37,39,41-45$. A study from the UK reported that $78 \%$ of physicians performed several types of DMP; however, only $37 \%$ of physicians older than 40 years old were engaged in such practices. The same study reported that the most common defensive medicine practice was to request extra tests with a rate of $59.3 \%$. Other DMP were reported as extra consultations at a rate of $54.3 \%$, carrying out extra procedures at a rate of $27.5 \%$, prescription of extra medicine at a rate of $23 \%$, and refusing high-risk patients at a rate of $9.3 \%$ [42]. While the mean DMP score of resident physicians at Dokuz Eylül University was $46 \pm 5.85$, Göçen et al. reported that this figure was $49.9 \pm 10.9$ in resident physicians of surgical specialties. In our study, the mean DMP score was $45.14 \pm 7.22$ and the rate of performing such practices was low compared to the literature. A similar study in 2016 reported that the mean DMP score was $47.13 \pm 8.09$ across the participating surgical and nonsurgical specialty physicians and general practitioners. The same study reported that the mean DMP scores were $44.16 \pm 10.31$ and $48.22 \pm 10.24$ for gynecology and obstetrics specialists. In our study, the mean DMP score of general surgeons was $43.3 \pm 9.19$ and this figure was lower than those reported in the literature previously ${ }^{30}$. Our study demonstrates that resident surgeons tend to engage in defensive medicine 
behaviors more commonly compared to specialists and faculty members, indicating the importance of raised knowledge level of resident surgeons. We think that the differences between the figures obtained in our study and in studies reported in the literature occurred due to the different characteristics of the distribution of participating physicians by their specialties in medicine and their academic titles. Examination of the DMP scores obtained in our study demonstrated that $10.3 \%$ (n $=4$ ) of physicians performed DMP at very high levels, $48.7 \%(\mathrm{n}=19)$ performed DMP at high levels, $35.9 \%$ $(\mathrm{n}=14)$ performed DMP at moderate levels, and $5.1 \%$ $(n=2)$ performed DMP at low levels. Based on our study results, it was concluded that surgeons were engaged in DMP at lower levels compared to the figures reported in the literature[3,33,35].

It was observed in our study that; compared to the specialists and faculty members, resident physicians ordered extra tests and provided their patients with as many prescriptions as possible within the limits of indication in order to protect themselves from liabilities ( $p$ <0.05). Also, ordering extra tests and refusing patients posing a high risk of being sued for malpractice were more commonly observed in female surgeons compared to their male colleagues $(\mathrm{p}<0.05)$. When the responses to the remaining questions were examined regarding the positive and negative defensive medicine; no statistically significant differences were observed between the resident surgeons and faculty members, between male and female surgeons, and between the surgeons with a patient relationship experience of longer and shorter than 10 years.

Resident physicians are more engaged in DMP compared to specialists based on both our study results and the results of studies reported in the literature. It has been reported that they practice DMP more commonly to avoid any malpractice litigations because their levels of knowledge and skills are low in their first years of career $[45,46]$. Similar to the reports in the literature, it was observed that male surgeons had a higher mean DMP score compared to their female colleagues in our study $[3,4]$.

In our study, $61.5 \%$ of the participating surgeons responded that they agreed moderately or at higher levels with the expression that they ordered extra tests for their patients to protect themselves from litigations. The rates in the literature range from $48.9 \%$ to $75 \%[31,33,34,42,47]$.

Prescribing as much indicated medicine as possible to the patients in order to be protected from legal problems was agreed at moderate and higher levels by the participating surgeons in our study at a rate of $58.9 \%$. The figures in the literature vary from 40 to $85 \%[4,29,31-35,47]$. Our study findings are parallel to the results reported in the literature.
In our study, $82.0 \%$ of the participating surgeons agreed at moderate and higher levels with the expression that they requested extra consultations to be protected from litigations, which might potentially be filed against them for potential complications. This rate varied in the literature from $61.7 \%$ to $90 \%$ [4,31$35,47]$.

In our study, $43.6 \%$ of the participants agreed at moderate and higher levels with the expression that; in order to be protected from legal problems, they hospitalized patients for extra causes other than indications. In the literature, this rate ranged from $34.8 \%$ to $90 \%[3,29,31-34,48]$. These results are compatible with the reports in the literature.

Ordering extra diagnostic tests for patients in order to be protected from legal problems was agreed at moderate and higher levels by the participating surgeons in our study at a rate of $74.4 \%$. The studies in the literature reported rates ranging from $40.3 \%$ to $100 \%$ (100\% for general surgeons) [3,22,31-34]. These results are in parallel to the results reported in the literature.

In our study, $89.8 \%$ of participating surgeons agreed at moderate or higher levels with the expression that they provided extra-detailed explanations to patients in order to be protected from legal problems. This figure is parallel to the figures reported in the range from $80.6 \%$ to $94.7 \%$ in the literature $[3,22,29,32,33,35,48]$.

In our study, $79.4 \%$ of participating surgeons agreed at moderate or higher levels with the expression that they allocated extra time to their patients in order to protect themselves from legal problems. In the literature, this figure was reported to be varying from $56.5 \%$ to $85.6 \%$ for physicians from several specialty areas in medicine $[3,32,33,35]$. The figure obtained in our study is compatible with the reports in the literature.

In our study, $79.5 \%$ of the participating surgeons agreed at moderate and higher levels with the expression that they kept extra-detailed patient records in order to be protected from legal problems. In the literature, this ratio was reported to be varying in the range from 85.9 to $93.8 \%$ in physicians from different specialty areas in medicine [3,29,31-35]. The figures obtained in our study are lower compared to the figures reported in the literature.

In our study, $92.3 \%$ of the participating surgeons agreed at moderate and higher levels with the expression that they exercised extra care in informed consent procedures in order to be protected from legal problems. Exercising extra care in informed consent procedures was reported in the literature at rates from 87.1 to $92.5 \% 3,29,31-33$. Therefore, the figure 
obtained in our study is parallel to the reports in the literature.

A study conducted on family physicians in England reported that $90.3 \%$ of the participants spent more time than usual while creating medical records and $86.6 \%$ provided much more detailed information to their patients while explaining the treatment plan to be provided in order to avoid possible medical malpractice cases 22 .

In our study; $59.0 \%$ of the participants agreed at moderate and higher levels with the expression that they avoided patients, who were likely to raise malpractice claims, in order to be protected from litigations. This was reported to be at variable rates from $55.5 \%$ to $67.9 \%$ by the studies in the literature $3,29,32,33,35$. The figure obtained in our study is compatible with the reports in the literature.

In our study, $41.0 \%$ of the participants agreed at moderate and higher levels with the expression that they avoided patients with complex medical problems in order to be protected from litigations. This ratio was found to be $44.4-64.6 \%$ in the literature [29]. The figure found in our study is lower compared to the rates reported in the literature [3,31-35].

In our study, $41.1 \%$ of the participants agreed at moderate and higher levels with the expression that they avoided treatment protocols with high complication rates. This rate was reported to be 54.6$73.6 \%$ in the literature [29]. The figure found in our study is lower compared to the rates reported in the literature [31-35].

In our study, $28.2 \%$ of the participants agreed at moderate or higher levels with the expression that they tended to prefer non-invasive treatment protocols rather than invasive ones in order to protect them from legal problems. This figure was reported to be between $54.5 \%$ and $74.1 \%$ in the literature. The figure found in our study is lower compared to the rates reported in the literature [4,31-33, 35].

In our study, $82.1 \%$ of the participants agreed at moderate or higher levels with the expression that they felt uneasy in medical practice as malpractice issues gain considerable media coverage. This rate was in the range from $81.5 \%$ to $91.4 \%$ in the literature $[3,30,32,33,35]$. Our study findings are compatible with the reports in the literature.

Hiyama et al. study on 131 gastroenterologists in Japan reported that defensive medicine was practiced by $98 \%$ of the participating physicians [37]. Avoidant behaviors were common in $96 \%$ of the physicians, including avoiding certain procedures or interventions or refusing to see high-risk patients. Of the participants, $75 \%$ reported that they avoided certain procedures or interventions. However, experienced gastroenterologists (who served for more than 20 years) practiced avoidance behavior less frequently than those who served for less than 10 years [37].

In our study, $81 \%$ of general surgery residents and $72.2 \%$ of specialists and faculty members reported that they had heard about the concept of defensive medicine before. However, it has been reported in the literature that $60.9 \%$ to $96.7 \%$ of physicians are aware of the concept of DMP 3,30,31,42. Of the participants in our study, $47.6 \%$ of the resident surgeons and $38.6 \%$ of the specialists and faculty members evaluated their level of knowledge about DMP as adequate. However; in the literature, it is reported that $16.1-41.9 \%$ of physicians evaluated their level of knowledge about DMP as adequate $4,30,31,33,35$. Of the general surgeons participating in our study, $97.4 \%$ reported that malpractice claim litigations would affect their performance in medical practice.

In conclusion; improved patient satisfaction, enhanced quality of healthcare services, and provision of detailed information to patients can be listed as examples for positive DMP. The disadvantages may include increasing rates of follow-up activities, high levels of monitoring efforts, and prescription of extra medicine. However, ordering a high number of diagnostic tests can be considered a defensive practice by a physician but it may be considered a good practice example by another physician.

\section{REFERENCES}

1. Başer A, İnci M, Kolcu B, Kolcu G, Balci UG. Defansif Tıp Uygulamaları Tutum Ölçeğinin Türkçe Formunun Geçerlilik Ve Güvenilirliği: Ön Çalışma. Tepecik Eğit Hast Derg. 2014;24(2):99102.

2. Hermer L BH. Defensive Medicine, Cost Containment, and Reform. J Gen Intern Med. 2010;25(5):470-473.

3. Kolcu G. TCSB İzmir Ege Doğumevi ve Kadın Hastalıkları Eğitim Ve Araştırma Hastanesi'nde Çalışan Kadın Hastalıkları Ve Doğum Uzmanı Hekimler ile Asistan Hekimlerin Defansif Tip Uygulamaları ile İlgili Görüşlerinin Değerlendirilmesi. 2013.

4. Kolcu G, Başer A, İnci M, Kolcu B, Balcı UG, Öngel K. Specialist and Assistant Gynecologists' Views about Defensive Medicine : Cross- sectional Study. Sch J Appl Med Sci. 2016;4(2A):326-330.

5. Wikipedia. Definition of Defensive Medicine. http://en.wikipedia.org/wiki/Defensive_medicine. Published 2018.

6. Studdert MD, Mello MM, Sage WM, DesRoches CM, Peugh J ZK. Defensive Medicine among High-Risk Specialist Physicians in a Volatile Malpractice Environment. JAMA J Am Med Assoc. 2005;293:2609-2617. 
7. Yargitay'da MK. 2010-2017 yılları arasında karara bağlanan tıbbi uygulama(malpraktis) dava kararlarının değerlendirilmesi; 2018.

8. Algan B. İstanbul'da yapılan adli otopsilerin tıbbi malpraktis açısından irdelenmesi. Uzmanlık tezi, İstanbul Üniversitesi Cerrahpaşa Tıp Fakültesi Adli T1p Anabilim Dalı.

9. Wilson RM, Runciman WB, Gibberd RW, Harrison BT, Newby L HJ. The Quality in Australian Health Care Study. Med J Aust. 1995;(163):458-471.

10. Güzel S, Yavuz MS AM. Adli Tıp Kurumu İhtisas Kurulları ile Yüksek Sağlık Şurası raporları arasında çelişki bulunan ve Adli Tıp Kurulu'nda görüşülen malpraktis olgularının irdelenmesi. Adli Tıp Bülteni. 2002;7(1):14-20.

11. Yazıcı AY, Şen H, Aliustaoğlu S, Sezer Y İC. Evaluation of the medical malpractice cases concluded in the General Assembly of Council of Forensic Medicine. Ulus Travma Acil Cerrahi Derg. 2015;21(3):204-208.

12. Can İÖ, Özkara E, Can M. Yargitayda karara bağlanan tıbbi uygulama hatası dosyalarının değerlendirilmesi. Dokuz Eylül Üniversitesi Tıp Fakültesi Dergisi. 2011;25(2):69-76.

13. Büken E, Ornek Büken N BB. Obstetric and gynecologic malpractice in Turkey: incidence, impact, causes and prevention. J Clin Forensic Med. 2004;(11):233-47.

14. Tümer AR. 1995-2000 Yıllarında Yüksek Sağlık Şurası'na Gelen Genel Cerrahi Vakalarının Malpraktis Yönünden Değerlendirilmesi. Ulusal Cerrahi Dergisi. 2003;19:11-6.

15. Studdert DM, Bismark MM, Mello MM, Singh H, Spittal MJ. Prevalence and characteristics of physicians prone to malpractice claims. New England Journal of Medicine. 2016 Jan 28;374(4):354-62.

16. Kayseri SK. Ölçeğinde tıbbi uygulama hatası iddialarının değerlendirilmesi.

17. Studdert DM, Mello MM, Gawande AA, Gandhi TK, Kachalia A, Yoon C, Puopolo AL BT. Claims, Errors, and Compensation Payments in Medical Malpractice Litigation. N Engl J Med. 2006;(354):2024-2033.

18. Polat O. Tıbbi Uygulama Hataları. Ankara: Seçkin yayınları; 2005.

19. Pakiş I. Ölüm ya da ölü doğumla sonuçlanan tıbbi uygulama hatalarına yaklaşımda adli otopsinin rolü. 2006.

20. Soysal Z. EM. Tibbi ve Cerrahi Tedavi Sırasında Meydana Gelen Ölümlerin Araştırılması Adli Tıp 1.Cilt. (Ed:Soysal Z ÇC, ed.). İstanbul: İstanbul Üniversitesi Cerrahpaşa Tıp Fakültesi Yayınları; 1999.

21. Başer A, Başer Kolcu M İ, Tuncer Ö AM. Diş Hekimlerinin Defansif Diş Hekimliği Konusundaki Görüşleri: Kesitsel Bir Çalışma. Tepecik Eğit Hast Derg. 2014;24(2):103-109.
22. Summerton N. Positive and negative factors in defensive medicine: a questionnaire study of general practitioners. BMJ. 1995;(310):27-29.

23. Özdemir E. Ölümlü Genel Cerrahi Tıbbi Uygulama hata iddiası bulunan olguların değerlendirilmesi. 2015.

24. Savaş H. Yargıya Yansıyan Tıbbi Müdahale Hataları. 1.Baskı. Ankara: Seçkin Yayıncılık; 2009.

25. Gürbeden B. 2010-2014 Yilları Arasında Tibbi Uygulama Hatası İddiası İle Adli Tıp Kurumu İzmir Grup Başkanlığında Otopsisi Yapılan Olguların Değerlendirilmesi. 2016.

26. Üzün İ, Özdemir E, Esen Melez İ, Melez DO AA. Ölümle sonuçlanan acil ve elektif genel cerrahi olgularında tıbbi uygulama hatasının değerlendirilmesi. Ulus Travma Acil Cerrahi Derg. 2016;22(4):365-373. doi:10.5505/tjtes.2015.26543

27. Wanzel K.R., Jamieson C.G. BJMA. Complications on a general surgery service: incidence and reporting. Can J Surg. 2000;43(2):113-117.

28. Şanyüz Ö, Birgen N, İçmeli ÖS. Tıbbi Uygulamalar ile ilgili Tazminat Davalarının Uzmanlık Alanlarına Göre Dağılımının Zorunlu Sağlık Sigorta Primlerinin Kademelendirilmesi. In: 9. Adli Bilimler Kongresi. İzmir; 153-154.

29. Mete B, Nacar E, Tekin C, Unver E GG. Investigation the defensive medical pracitces of the physicians working in the city center of Malatya. Med Sci. 2017;6(2):270-275.

30. Özata M, Özer K AY. Konya il merkezinde çalışan hekimlerde defansif (çekinik)tıp uygulamalarının araştırması. GÜSBD. 2018;7(1):132-139.

31. Selçuk M. Çekinik (defansif) tıp. Sağlık Hukuku; 2015.

32. Göçen Ö, Yılmaz A, Aslanhan H, Çelepoğlu T, Tuncay $S$ DE. Hekimlerin Defansif Tip Uygulamaları Hakkında Bilgi ve Tutumları, İşe Bağlı Gerginlik ve Tükenmişlik Düzeyleri. TJFMPC. 2018; 12(2). www.tjfmpc.gen.tr.

33. Biçen E. Tıpta uzmanlık öğrencilerinin defansif tıp konusundaki tutumlarının araştırılması; 2018.

34. Yilmaz K. Defansif Tip Hekimin Tibbi Uygulamalarda Sorumluluktan Kaçması Durumunda Ortaya Çıkan Problemler. Birinci Ba. Ankara: Seçkin Hukuk; 2014.

35. Başer A, Kolcu G, Çığırgil Y, Kadınkız B ÖK. İzmir Karşıyaka ilçesinde görev yapan aile hekimlerinin defansif tıp uygulamaları ile ilgili görüşlerinin değerlendirilmesi. Symrna Tıp Derg. 2014;(16):24.

36. Solaroglu I, Izci Y, Yeter Gokce, Metin MM KG. Health tranformation Project and defensive medicine practice among neurosurgeons in Turkey. PLoS One. 9(10:e 111446). doi:10.1371/journal.pone.0111446

37. Hiyama $T$, Yoshihara M, Tanaka S, Urabe Y, Ikegami Y, Fukuhara T, Chayama K. Defensive medicine practices among gastroenterologists in 
Japan. World journal of gastroenterology: WJG. 2006 Dec 21;12(47):7671.

38. Chen KY, Yang CM, Lien CH, Chiou HY, Lin MR, Chang HR, Chiu WT. Burnout, job satisfaction, and medical malpractice among physicians. International journal of medical sciences. 2013;10(11):1471.

39. Asher E, Greenberg-Dotan S, Halevy J, Glick S RH. Defensive ve Medicine in Israel-A Nationwide Survey. PLoS One. 2012;7(8:e42613).

40. Aynac1 Y. Hekimlerde defansif (çekinik) tıp uygulamalarının araştırılması (Doctoral dissertation, Selçuk Üniversitesi Tıp Fakültesi); 2008.

41. Moosazadeh M, Movahednia M, Movahednia N, Amiresmaili M AI. Determining the frquency of defensive medicine among general practitioner in southeast. Iran Int $\mathrm{J}$ Heal Policu Manag. 2014;2(3):119-123. doi:10.15171/ijhpm.2014.28

42. Ortashi $O$. The practice of defensive medicine among hospital doctors in the United Kingdom. BMC Med Ethics. 2013;14(1):42.
43. Traina F. Medical malpractice: the experience in Italy. Clinical orthopaedics and related research. 2009 Feb 1;467(2):434-42.

44. Osti $M$ and JS. A national survey of defensive medicine among orthopaedic surgeons, trauma surgeons and radiologists in Austria: evaluation of prevalence and context. J Eval Clin Pract. 2015;21(2):278-284.

45. Leung PK. Defensive practice among psyhiatrists: a questionnaiire survey. Postgr Med J. 2002;(78):671-673.

46. Yeşiltaş A ER. Defansif tıp uygulamalarına yönelik bir derleme. Süleyman Demirel Üniversitesi vizyoner Derg. 2019;10(23):137-150.

47. Nahed BV, Babu MA, Smith TR HR. Malpractice Liability and Defensive Medicine: A National Survey of Neurosurgeons. PLoS One. 2012;7(6:e39237).

48. Göçen Ö, Yılmaz A, Aslanhan H, Celepkolu T, Tuncay S, Dirican E. Assistant Physicians Knowledge and Attitudes about Defensive Medical Practices, Work-Related Stress and Burnout Levels. Turkish J FAM Med Prim Care. 2018;12(2):77-87. 